\author{
SYLWIA CHMURA \\ ORCID: 0000-0002-6863-4515 \\ Uniwersytet Wrocławski \\ sylwia.chmura@uwr.edu.pl
}

\title{
Historyczna ewolucja independentyzmu katalońskiego. Formowanie się katalonizmu poprzez działalność regionalnych ruchów społecznych
}

Słowa kluczowe: Katalonia, katalonizm, niepodległość, ruchy społeczne, protest, manifestacja, nacjonalizm.

HISTORICAL EVOLUTION OF CATALONIAN INDEPENDENTISM. THE FORMATION OF CATALONISM THROUGH THE ACTIVITY OF REGIONAL SOCIAL MOVEMENTS

Abstract:

The article contains an analysis of the historical development of Catalan nationalism, its evolution from the early Middle Ages to modern times. It points to the key role of social movements in the political process of protecting the Catalan identity from being degraded or completely eliminated by the Spanish central government. The depth of the region's history points to several basic conclusions. Mainly, the image of Catalan separatism as a temporary "rush" of citizens, shaped by Catalan's modern political elite to divert attention from the corruption scandals is untrue. The analysis of the rich history of Catalan political culture indicates that the phenomenon of Catalanism has become a constant.

Keywords: Catalonia, Catalanism, independence, social movements.

\section{Wstęp}

Celem artykułu jest przedstawienie nacjonalizmu katalońskiego i jego historycznej ewolucji z perspektywy tworzenia oraz działalności starych i nowych ruchów społecznych definiowanych w ramach teorii Manuela Castellsa. Krytyczna analiza historii regionu prowadzi do postawienia hipotezy zakładającej, że separa- 
tyzm kataloński ma charakter permanentny. Nie stanowi on epizodycznego zjawiska we współczesnej historii Hiszpanii, a wręcz przeciwnie, kultura protestu jest zakorzeniona w tradycji regionu. Katalonizm można zinterpretować jako działanie społeczeństwa katalońskiego, mające na celu wyrażenie tożsamości regionalnej w opozycji do nacjonalizmu państwowego. Analiza historii regionu pozwala wyprowadzić wniosek, że organizacje i związki obywatelskie o charakterze nieformalnym oraz publiczne manifestacje i marsze stanowiły główny czynnik kształtujący tożsamość katalońską.

Artykuł w swojej warstwie teoretycznej opiera się na krytycznej analizie zjawiska ruchów społecznych, przedstawionej w ramach teorii socjologicznej nowych ruchów społecznych. Jak wskazuje Claus Offe, należy wyodrębnić podział na dwa typy ruchów: stare i nowe. W odniesieniu do katalońskiej sceny politycznej za ruchy społeczne starego typu można uznać partie regionalne o poglądach nacjonalistycznych i separatystycznych. Cechy zgodne z typologią nowych ruchów społecznych wykazują zaś pozarządowe organizacje obywatelskie, zrzeszenia i związki o nieformalnym charakterze ${ }^{1}$.

Powstawanie i działalność ruchów społecznych można zaobserwować od momentu tworzenia się politycznej odrębności Katalonii aż do współczesnej sytuacji kryzysu politycznego związanego z referendum niepodległościowym. De facto do lat sześćdziesiątych XX wieku dominującą rolę odgrywały stare ruchy społeczne (partie $\mathrm{i}$ hierarchicznie zbudowane organizacje polityczne). Wraz z postępem technologicznym, wzrostem świadomości społecznej, a także przeobrażeniami związanymi z globalizacją dostrzegalna stała się wzrastająca rola organizacji pozarządowych. Zmieniły się główne cele członków ruchów społecznych w Katalonii: od obrony specyfiki tożsamości kulturowej po walkę o prawa do wolności politycznej, swobody wyboru, wolności głosowania, organizacji referendów i wyrażania poglądów. Inaczej mówiąc, ruchy społeczne z kulturowych przekształciły się w polityczne. Stopniowo organizacje polityczne radykalizowały swoje postulaty, przeobrażając się z ruchów funkcjonujących w nurcie łagodnego nacjonalizmu w organizacje separatystyczne, których podstawowym celem było stworzenie własnego państwa. Jak wskazuje William Gamson w teorii wpływu ruchów społecznych, odgrywają one kluczową rolę w osiąganiu celów stawianych przez grupę społeczną ${ }^{2}$.

\section{Kwestie definicyjne}

W szkołach hiszpańskich historia i edukacja językowa od początków konfliktu pomiędzy władzą centralną a Katalonią stanowiły główne obszary sprze-

${ }^{1}$ C. Offe, New social movements. Challenging the boundaries of institutional politics, „Social Research" 1985, nr 52 (4), s. 821, 825-826.

2 W. Gamson, Strategy of Social Protest, Belmont 1975, s. 10. 
ciwu. Obie strony sporu stworzyły własne interpretacje wydarzeń historycznych, związane z tradycjami politycznymi obu regionów (Katalonia jest ideologicznie republikańska/lewicowa, natomiast Madryt zwykle konserwatywny). Katalońskie organizacje, partie i ruchy społeczne można kategoryzować zgodnie z teorią społeczeństwa sieci, a szczególnie teorią nowych ruchów społecznych Manuela Castellsa. Dokonał on podziału na stare i nowe ruchy społeczne, wskazując na ich cechy dystynktywne. Cytując tego badacza, „stare ruchy społeczne to sformalizowane instytucje i organizacje, które funkcjonują w ramach określonej struktury, formułują jasny program oraz tworzą formalne zasady i spisane normy działania. Głównym czynnikiem skuteczności jest silny przywódca ugrupowania, który prze-

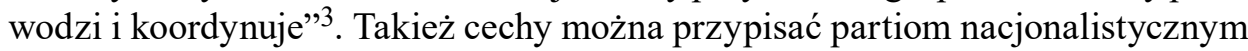
i separatystycznym w rządzie katalońskim. Natomiast ,nowe ruchy społeczne to rodzaj wspólnoty poglądów, brak im formalizmu, nie posiadają hierarchii, stałego, jasnego programu. Ruchy tego typu nie wyłaniają formalnego przywódcy. Wszyscy członkowie nowych ruchów społecznych posiadają równorzędny status i każdy głos ma tą samą wagę ${ }^{\text {"4 }}$. Castells wskazuje na potencjał polityczny świadomego, kolektywnego działania podejmowanego w określonych czasowo i kulturowo ramach 5 .

W odniesieniu do Katalonii badanym podmiotem jest grupa popierająca niepodległość regionu, rozumiana jako obywatele wyrażający poglądy proniepodległościowe poprzez organizację protestów, manifestacji, okupowanie przestrzeni publicznej. Istotnym elementem zaangażowania politycznego Katalończyków jest udział w referendach, wyborach oraz swobodna aktywność polityczna w sieci. Proces formowania się organizacji ruchów społecznych stanowi istotny element działalności proniepodległościowej. Jak wskazuje Sidney Tarrow, strategia oporu i wykorzystywania krytycznych epizodów przez te ruchy jest powszechna ${ }^{6}$.

Kolejnym z fundamentów teorii Castellsa jest teza o konfliktowym/opozycyjnym charakterze ruchów społecznych. Są one formą grupowej manifestacji rozczarowania dominującą kulturą i organizacją. Źródłem działania staje się opinia o niemożliwości osiągnięcia samorealizacji w istniejącej strukturze. Ruchy społeczne zawsze na którymś z etapów swojego istnienia wchodzą w konflikt z grupami głównego nurtu kultury (hiszpański rząd centralny i kultura kastylijska jako uniwersalna, państwowa, najważniejsza). Zmiany dokonywane przez te ruchy to jakościowe przeobrażenia struktury dominującej w kraju, w którym one działają, powodujące niestabilność instytucjonalną ${ }^{7}$.

Szczególnie ważnym dla analizy przypadku Katalonii elementem teorii ruchów społecznych Castellsa jest określenie relacji pomiędzy tożsamością nowych

\footnotetext{
3 M. Castells, The Power of Identity, Malden 2004, s. 3, 114.

${ }^{4}$ M. Castells, The City of the grassroots, Oakland 1983, s. 276.

5 M. Castells, The Rise of the Network Society, Oxford 2000, s. 163-164.

6 S. Tarrow, Power in Movement, Cambridge 2009, s. 38-39.

7 F. Stalder, M. Castells. Teoria społeczeństwa sieci, przeł. M. Król, Kraków 2012, s. 91-122.
} 
ruchów społecznych a dominującymi wartościami polityki wewnętrznej współczesnego państwa. Hiszpański badacz dokonał podziału tożsamości kolektywnej na trzy grupy: „tożsamość legitymizującą”, „tożsamość oporu”, „tożsamość projektu”. Pierwszą z nich na gruncie katalońskim prezentują stare ruchy społeczne, partie niepodległościowe, organizacje i związki zawodowe. Natomiast nowe ruchy społeczne, zgodnie z tą teorią, mogą przejawiać albo tożsamość oporu, albo projektu. Katalońskie ruchy społeczne mają cechy grup tożsamości oporu, gdyż sprzeciwiają się dominującej w kraju narracji. Silne jest również zgodne z definicją tego rodzaju tożsamości poczucie stygmatyzacji przez władzę centralną. Omawiane ruchy regionalne wpisują się w założenia o przyjmowaniu strategii kontrastowania własnej tożsamości z dominującą. Jak wskazuje Castells, „Wszystkie te grupy sytuują siebie poza dominującą kulturą, na podstawie własnej tożsamości. Nie postulują integracji, lecz separację" ${ }^{8}$. Za fundament teoretyczny niniejszej pracy uznaję tezę hiszpańskiego socjologa, że ruchy społeczne są narzędziem pozwalającym marginalizowanym przez lata kulturom powrócić do głównego nurtu polityki państwowej i dokonać transformacji struktury społecznej. Oparcie tej teorii na kwestiach kulturowych w polityce i interpretacja władzy jako zdolności do tworzenia kodów kulturowych stanowią najlepsze narzędzie do analizy społeczności zwolenników niepodległości Katalonii. Znamienne jest tutaj spostrzeżenie, że ruchy społeczne tworzą własne hiperteksty ${ }^{9}$, które powodują coraz większe podziały kulturowe. W sytuacji, gdy pojawia się kryzys instytucji demokratycznych, racjonalny dyskurs i kompromis są porzucane na rzecz radykalnych rozwiązań ${ }^{10}$.

\section{Początki nacjonalizmu katalońskiego}

Termin „Katalonia” upowszechnił się w XII wieku. Początkowo w ten sposób określano wspólnotę ludzi oraz ziem, których zarządcą był hrabia Ramon Berenguer III (1082-1131) ${ }^{11}$. Ten jednolity administracyjnie obszar przekształcił się w organizm państwowy, posiadający wyodrębnioną strukturę społeczną; powstała wspólnota ludzi o własnym języku i odrębnej kulturze. Zjednoczone pod panowaniem hrabiego Barcelony tereny już w tym czasie wykazywały odrębność od pozostałych regionów hiszpańskich. To w epoce średniowiecza pojawiły się pierwsze

8 M. Castells, The Power of..., s. 23-24.

9 Jak podają Ikujiro Nonaka i Hirotaka Takeuchi: „Pod pojęciem hipertekstu rozumieć należy tekst złożony $\mathrm{z}$ wielu warstw. Tekst w ujęciu zwyczajowym posiada jedną warstwą — sam tekst, natomiast hipertekst tworzą różne warstwy tekstów, stanowiące dostępne konteksty". Zob. I. Nonaka, H. Takeuchi, Kreowanie wiedzy w organizacji. Jak spótki japońskie dynamizuja procesy innowacyjne, przeł. E. Nalewajko, Warszawa 2000, s. 202.

${ }_{10}$ M. Castells, Siła tożsamości, s. 23-24.

11 P. Freedman, Cowardice, heroism and the legendary origins of Catalonia, „Past \& Present" 1988 , nr 121, s. 3-20. 
projekty akcentujące niezależność Katalonii ${ }^{12}$. W dyskusji wokół jednoczenia ziem hiszpańskich Katalończycy opowiadali się za budową państwa tolerancyjnego, poszanowaniem różnic między narodowościami hiszpańskimi i odrzucali głęboki centralizm. Systemem wdrażanym w regionie był tak zwany paktyzm, odpowiednik teorii konstytucjonalizmu. Początki współczesnego nacjonalizmu w Katalonii datuje się na połowę XIX wieku, około stu lat po utracie katalońskich fueros ${ }^{13}$.

Punkt zwrotny w konflikcie pomiędzy władzą centralną a regionem Katalonii miał miejsce po zakończeniu wojny o sukcesję hiszpańską, gdy Filip V Hiszpański wydał zbiór dekretów znanych w języku hiszpańskim jako Decretos de Nueva Planta (katal. Decrets de Nova Planta). Nowy zestaw aktów anulował pierwsze odrębne prawa terytoriów (fueros); postanowienie to obejmowało wszystkie terytoria Korony Aragońskiej, z wyjątkiem Doliny Arán, Nawarry i Prowincji Baskijskich. Dokument ten miał być konsekwencją opowiedzenia się regionów po stronie Habsburgów w wojnie o sukcesję. Decretos miały za zadanie doprowadzić do całkowitej centralizacji Hiszpanii (na wzór Francji), ujednolicając system prawny i administracyjny. Największy sprzeciw wśród Katalończyków wywołało narzucenie języka kastylijskiego jako obowiązującego na całym terytorium państwa. Król ogłosił pierwsze dekrety w 1707 roku, a ostatni, czwarty z kolei, 16 października 1716 roku (poświęcony wyłącznie Królestwu Katalonii i Balearów). Wprowadzenie nowego prawa oznaczało utratę dotychczasowych przywilejów na rzecz przymusowej standaryzacji i uniwersalizacji kultury kastylijskiej ${ }^{14}$

Postanowienia dokumentów nakazywały likwidację organów władzy regionalnej Generalitat de Catalunya, Cortes Catalanas i Consell de Cent ${ }^{15}$. Stanowisko wicekróla zastąpiono urzędem kapitana generalnego, zmniejszając przy tym przysługujący mu zakres kompetencyjny, podobnie jak we wszystkich pozostałych królestwach Korony Aragonii. Nowy podział administracyjny zakładał powstanie dwunastu corregidur, tak jak w Kastylii, i likwidację katalońskiego systemu administracyjnego złożonego z piętnastu vegueríes i ośmiu sotsvegueries. Ustanowiono tak zwany kataster (el catastro), obejmujący własność miejską i wiejską, zyski z pracy, handlu i przemysłu. Język kataloński utracił status języka oficjalnego

\section{Ibidem}

13 Prawa Księstwa Katalonii ogłaszane przez hrabiego Barcelony, a następnie zatwierdzane przez katalońskie sądy. Pierwsze fueros zostały ogłoszone przez Kortezy w 1283 roku, kolejne w 1413, 1585, oraz w 1705 roku. Były one specyficzne dla krain historycznych i nadawały wyjątkowy status wyróżnionym regionom hiszpańskim. Miały pierwszeństwo przed innymi przepisami prawa krajowego i mogły zostać odwołane tylko przez same sądy katalońskie. Zob. Fueros de Cataluña: resúmen histórico-legal de los principales usages, constituciones, derechos y franquicias que se observan en el antiguo principado Catalonia (Spain), Gerona 1870, s. 8-9.

${ }^{14}$ Cartas Acordadas Real Audiencia, Archivo de la Corona de Aragón, ACA,REAL AUDIENCIA,Registros,6; Decreto de Nueva Planta, 1716, http://pares.mcu.es/ParesBusquedas20/ catalogo/description/3281950 (dostęp: 22.11.2019).

15 Organ legislacyjny istniejący od XIII do XVIII wieku, zwoływany przez króla; podzielony na trzy części: królewską, wojskową/szlachecką i duchowieństwa. 
i został zastąpiony kastylijskim, wprowadzono również obowiązek posługiwania się nim w szkołach i sądach. Uniwersytety katalońskie, które wsparły kandydata Habsburgów, zostały zamknięte - wyjątkiem była uczelnia w Cervera, która dotrzymała wierności Filipowi V. Dekret nie zmieniał jednak zapisów prawa cywilnego, karnego i procesowego, zachowano również organ Consulado del Mar ${ }^{16}$.

Historia Katalonii po 1714 roku naznaczona była konsekwentnymi próbami walki o przywrócenie instytucji demokratycznych, utraconych pod rządami Filipa V. Dowodzi to tego, że od ponad trzystu lat Katalończycy, niezależnie od wyznawanej przez nich ideologii politycznej, lobbowali za większą autonomią i uznaniem dla katalońskich elementów tożsamości kulturowej i językowej ${ }^{17}$.

Za pierwszy masowy przejaw katalońskiego nieposłuszeństwa obywatelskiego można uznać bunt chłopski bunt z 1640 roku, w historii określany jako wojna żniwiarzy (Guerra dels Segadors ${ }^{18}$ ). Był on formą powstania zbrojnego, skierowanego przeciwko Filipowi IV Habsburgowi. Natomiast pierwsze postulaty wyrażające dążenia do pełnej niezależności Katalonii od Hiszpanii zaczęły być wysuwane w latach $1850-1910^{19}$.

Analizując historię Katalonii pod względem relacji organizacji społecznych z ruchem nacjonalistycznym, pierwotne ruchy, wobec których można próbować stosować teorię Manuela Castellsa, można dostrzec w średniowieczu. To wtedy powstawały pierwsze ruchy chłopskie o charakterze protestacyjnym przeciwko panom hiszpańskim. Pod koniec średniowiecza w polityce wewnętrznej Królestwa Katalonii i Aragonii nastąpił permanentny kryzys. Był to okres ciągłych buntów chłopskich, walk możnych ze sobą oraz burżuazji z mieszczaństwem, których powodem były zbyt rozbudowane przywileje najbogatszych członków drugiej z tych grup $^{20}$. Pierwszą znaną rebelią był tak zwany bunt Berenguera Olleara z 1285 roku. Przyczyną pojawienia się chłopskich ruchów oporu była ogólna atmosfera buntów społecznych w regionie Morza Śródziemnego, w szczególności w miastach włoskich i francuskich, których źródłem były zwiększające się różnice dochodowe w obrębie społeczeństwa miejskiego ${ }^{21}$.

${ }^{16}$ Konsulaty Morza były średniowieczną instytucją prawno-handlową tworzoną przez przeora i kilku konsulów, których jurysdykcja działała podobnie do obecnych sądów handlowych. Instytucja Konsulatów Morza pierwotnie wywodzi się z regionu Morza Śródziemnego, pierwszy z nich powstał pod Trani (Włochy) w 1063 roku. Zob. El Consulado del Mar, http://www.casallotja.com/ introducci (dostęp: 22.11.2019).

17 A. Domínguez Ortiz, The Revolt of Catalonia against Philip IV, „Past \& Present” 1964, nr 39, s. 220.

18 N. Florensa i Soler, M. Güell, PRO DEO, PRO REGI, ET PRO PATRIA. La revolució catalana i la campanya militar de 1640 a les terres de Tarragona, Barcelona 2005, s. 102.

19 R. Guise, Two Wheels Over Catalonia. Cycling the Back Roads of North-Eastern Spain, Chichester 2011, s. 263.

20 J. Roca i Albert, Miejsce Barcelony w cywilizacji europejskiej, przeł. S. Kuźmicz, [w:] Barcelona i Kraków. Zmieniające się wizje - wizje zmian. Materiaty międzynarodowej konferencji zorganizowanej w dniach 29-30 marca 2007, red. J. Purchla, Kraków 2008, s. 22.

${ }^{21}$ K. McRoberts, Catalonia. Nation Building Without a State, New York-Oxford 2001, s. 143. 
Po wybuchu wojny trzydziestoletniej, w 1626 roku, Filip IV, hrabia Olivares, ogłosił na podległych mu terenach wprowadzenie nowego, nieproporcjonalnego systemu podatków i poborów, nazywanego Unią Broni. Ponadto w tym samym czasie do wzrostu niezadowolenia i napiętych nastrojów przyczyniło się również stacjonowanie wojsk kastylijskich w Katalonii. Siły te zostały tam rozlokowane pod pretekstem ochrony granic przed zagrożeniem ze strony Francji. W efekcie doszło do wybuchu krwawego buntu żniwiarzy w Barcelonie w 1640 roku, w którego wyniku Generalitat Katalonii ogłosił niepodległość pod ochroną Francji. Wybuchła wojna, która w ostateczności zakończyła się wygraną wojsk króla Hiszpanii i utratą przez Francuzów północnej Katalonii 22 .

Kolejną z przyczyn buntu katalońskich chłopów były nowe reformy w zakresie podatków i danin. Król nakazał wprowadzenie nowych obciążeń, wskazując, że Katalończycy byli dotychczas niesprawiedliwie uprzywilejowani i powinni ponosić odpowiedzialność za udział w kampaniach wojskowych Kastylii, zarówno pod względem finansowym, jak i wykorzystania siły roboczej ${ }^{23}$.

Wojna żeńców wybuchła w dniu 22 maja 1640 roku, kiedy to katalońscy chłopi zwrócili się przeciwko wojskom kastylijskim. Prezydent Generalitat Pau Claris rozpoczął tajne pertraktacje $\mathrm{z}$ kardynałem Richelieu, pierwszym ministrem Francji, w celu uzyskania pomocy w uniezależnieniu się regionu od Kastylii. Ponad trzy tysiące chłopów z regionu Vallès w środkowej Katalonii rozpoczęło pod przewodnictwem biskupów Vic i Barcelony przemarsz do stolicy Katalonii. Momentem krytycznym okazało się zdarzenie z dnia 7 czerwca 1640 roku, czyli w dzień święta Bożego Ciała - po serii mniejszych starć z wojskami Kastylii jeden ze żniwiarzy został zabity. W odpowiedzi grupa oburzonych chłopów ogłosiła flagę parafii Sant Andreu swoim sztandarem i wyruszyła do Barcelony. Powstanie przerodziło się następnie w ruch narodowo-wyzwoleńczy ze stale rosnącą liczbą zwolenników. $Z$ tego okresu pochodzi również pieśń będąca obecnie hymnem regionu, co dowodzi wagi tego zdarzenia dla tożsamości katalońskiej24.

W wyniku buntu 16 stycznia 1641 roku przedstawiciel katalońskiego Generalitat, Pau Claris, ogłosił niepodległość Republiki Katalonii. Na mocy traktatu z Ceret została proklamowana tak zwana Republika Miejska. Zgodnie z powyższymi postanowieniami Katalonia stała się niepodległym państwem pod ochroną Francji ${ }^{25}$. Ostatecznie jednak powstanie zostało stłumione przez wojska kastylijskie, republika zaś została zlikwidowana. Wprowadzono ograniczenia praw autonomicznych regionu ${ }^{26}$. Wybuch wojny trzydziestoletniej spowodował podział

22 D. Conversi, Language or race? The choice of core values in the development of Catalan and Basque nationalisms, „Ethnic and Racial Studies” 1990, nr 13, s. 56; R. Guise, op. cit., s. 264.

23 R. Guise, op. cit., s. 265.

24 R. Guise, op. cit., s. 267, 315.

25 M.A. Vargas, Constructing Catalan Identity. Memory, Imagination, and the Medieval, Cham 2018, s. 50.

26 Ibidem. 
Katalonii pomiędzy Francję i Hiszpanię. Nastąpił wtedy stan permanentnego niepokoju i napięcia w społeczeństwie katalońskim, którego skutkiem były liczne ruchy oporu i masowe bunty. Szanse na niepodległość Katalonii ostatecznie zostały rozwiane po uchwaleniu traktatu westfalskiego w 1648 roku $^{27}$.

U schyłku XVII wieku, w latach 1688-1689, miało miejsce jeszcze jedno chłopskie powstanie, tak zwane powstanie barretines (nazwa ta pochodzi od nakrycia głowy buntowników). Po początkowym sukcesie, gdy powstańcy zajęli Barcelonę i zyskali szereg ustępstw od władz, kastylijska elita ostatecznie zdusiła rewoltę ${ }^{28}$.

W latach 1705-1714 w Barcelonie wybuchł następny antyhiszpański bunt, tak zwana ,wojna o sukcesję”, wymierzony przeciwko rządom Filipa V Burbona, który został brutalnie stłumiony. Katalonia została zmuszona do posłuszeństwa i poddania się wojskom Filipa V. Skutkiem nieudanego puczu była utrata niezależnej władzy politycznej przez rząd kataloński. Regionowi zostały odebrane na mocy tak zwanych Decretos de Nueva Planta wszystkie przyznane wcześniej przywileje. W myśl tych dokumentów kontrolę nad Katalonią przejął zarząd wojskowy, ponadto osłabiono samodzielność regionu, likwidując jakiekolwiek przejawy autonomii, zmniejszono rolę Barcelony oraz przeprowadzono proces unifikacji i kastylizacji tego obszaru. Dokonano także podziału Katalonii na część francuską i hiszpańską na mocy ostatniego, stricte dotyczącego Katalonii, dekretu z 1720 roku $^{29}$.

Pod koniec lat dwudziestych XVII wieku zaczęły narastać protesty przeciwko funkcjonowaniu rad miejskich, ustanowionych na mocy Decretos de Nueva Planta, będących częścią struktury administracyjno-prawnej narzuconych Katalonii rządów wojskowych. Skargi dotyczyły porządków ustanowionych w ramach utworzonych w myśl powyższego aktu jednostek administracyjnych, tak zwanych regidores i corregidores. Protesty inicjowały na ogół gildie - formalne, polityczne i społeczne organizacje zawodowe. Głównym postulatem protestujących było zniesienie obowiązującego systemu na rzecz lokalnej struktury administracyjnej ${ }^{30}$.

Kolejnym etapem dążeń do odzyskania odebranych Katalończykom praw był ich udział w trzech wojnach karlistowskich — w latach 1833-1839 (I wojna karlistowska), 1847-1850 (II wojna karlistowska) oraz 1868-1876 (III wojna karlistowska) — spowodowanych kryzysem sukcesyjnym w dynastii Burbonów po śmierci Ferdynanda VII. Karliści stanowili ruch zwolenników osadzenia na tronie brata króla, Don Carlosa. Konflikt ten, o podłożu ideologicznym i sukcesyjnym, był skierowany przeciwko liberalnej grupie wspierającej regentkę Marię Krystynę. Grupy karlistowskie, choć pod względem ideologicznym były złożone z konser-

27 R. Hughes, The Spectacle of Skill. Selected Writings of Robert Hughes, New York 2015, s. $221-222$.

28 A. Sroka, Hiszpańska droga do federalizmu, Wrocław 2008, s. 52.

29 M. Pohlig, M. Schaich, The War of the Spanish Succession. New Perspectives, Oxford 2018, s. 15.

${ }^{30}$ Ibidem, s. 356. 
watystów o silnych poglądach tradycjonalistycznych i katolickich oraz postulowały konserwatywną „kontrreformację”, zyskały spore poparcie wśród katalońskiego chłopstwa. Głównym postulatem karlistów była antyabsolutystyczna decentralizacja kraju, co w sposób oczywisty zapewniało jej poparcie i zaangażowanie ze strony ruchów w Katalonii ${ }^{31}$.

\section{Kulturowe podstawy independentyzmu - ruch Renaixença}

Powstanie ruchu kulturowej tożsamości datuje się na XIX wiek. Jak wskazuje Miroslav Hroch, kataloński ruch romantyczny (Renaixença) był tworzony przez przedstawicieli wyższych klas społecznych (głównie bogatych właścicieli ziemskich i duchowieństwa, bogatych kupców i inteligencji). Według tego badacza należało zatem sklasyfikować ruch ten jako „zdezintegrowany ruch polityczny”32. Stanowił on zatem przeciwieństwo średniowiecznych chłopskich ruchów oporu. Tym samym idea katalonizmu rozpowszechniała się na kolejne klasy społeczne. Jednocześnie dzięki zainteresowaniu nią ze strony środowisk intelektualnych ruch regionalny zyskał fundament dla wykreowania swojego programu ideologicznego, jasnego określenia celów i koordynacji dotąd niezorganizowanej działalności ${ }^{33}$.

Termin Renaixença wywodzi się od tytułu czasopisma, które w latach 18711905 promowało restaurację języka katalońskiego. Renaixença była pierwszym zorganizowanym wokół jasno zdefiniowanego programu ruchem na rzecz odrodzenia kultury i języka katalońskiego. Po latach stagnacji spowodowanej wspominanymi wcześniej dekretami jego pobudzenie było możliwe dzięki rewolucji przemysłowej i powszechnemu odrodzeniu romantyzmu w Europie. Dwoma głównymi celami Renaixença było przywrócenie szacunku dla języka katalońskiego i stworzenie literatury narodowej. Organizacja ta wyraźnie wykraczała poza aspekty kulturowe, szybko ulegając procesowi upolitycznienia. Najważniejszym zadaniem tego ruchu było wykreowanie silnej tożsamości katalońskiej wśród społeczeństwa (bazującej na tak zwanych hechos diferenciales, oznaczających podkreślanie różnic pomiędzy Katalonią a pozostałymi regionami). Najbardziej znanymi członkami ruchu byli Pablo Picasso i Joan Miró. Jak wiadomo, Renaixença składała się w dużej mierze z przedstawicieli elit kulturalnych, literatów o wysokim stopniu znajomości regionalnego dziedzictwa kulturalnego, historycznego i językowo-literackiego. Jednak mimo że Renaixença była ruchem literackiej, naukowej mniejszości, postulaty ochrony kultury nie były zupełnie oddzielone od kwestii politycznych. Problem zapewnienia tożsamości kulturowej nieuchronnie łączył się

31 J. Falkner, The War of the Spanish Succession 1701-1714, South Yorkshire 2015, s. 79, 94, 96, 160, 188.

32 M. Hroch, Mate narody Europy. Perspektywa historyczna, Wrocław 2003, s. 81-94.

33 Ibidem. 
z innymi katalońskimi obawami, szczególnie z protekcjonizmem gospodarczym i niezadowoleniem z kastylijskiego centralizmu. Lęki te wywołały nacisk na stworzenie nowej koncepcji umocowania politycznego Katalonii w ramach Hiszpanii: autonomii lub ograniczonych samorządów. Tym samym ruch nacjonalistyczny przeszedł do drugiego etapu swojego działania, o charakterze politycznym. Postulaty nawołujące do reformy struktury organizacyjnej regionu szczególnie wyraźnie wybrzmiewały po upadku pierwszej Republiki (1873-1874), której trzech prezydentów było Katalończykami. To właśnie w okresie post-republiki, czyli Przywróceniu, nastąpiła faza dążenia do uznania specjalnego statusu dla Katalonii. Powstała wtedy Lliga Catalana (Liga Katalońska), która opowiadała się za uzyskaniem samorządności lub autonomii regionu (choć nie postulowano otwarcie secesji Katalonii od Hiszpanii) ${ }^{34}$.

Na początku XX wieku nastąpił szybki rozwój katalońskiego nacjonalizmu politycznego. Jak wiemy, już pod koniec XIX wieku pojawiały się rosnące tendencje autonomiczne. Połączenie środkowo-peryferyjnych nierówności społecznoekonomicznych z ideami filozofii romantyzmu niemieckiego pozwoliło na zyskanie poparcia społecznego dla głoszonych przez nacjonalistów postulatów. Domagający się protekcjonizmu gospodarczego i własnych praw politycznych przemysłowcy poszukiwali uzasadnienia swoich żądań, które odnaleźli w założeniach programowych nacjonalizmu ${ }^{35}$.

Mimo że ruch Renaixença był początkowo organizacją ekskluzywną, złożoną jedynie z elit burżuazyjnych, szybko zyskiwał popularność także wśród innych warstw społeczeństwa, takich jak robotnicy miejscy, a co istotne, również wiejskiej arystokracji — muntanyesos — która później stała się jego główną siła napędową ${ }^{36}$.

Działalność Renaixença połączyła Katalończyków we wspólnotę opartą na szczególnym znaczeniu lokalnego języka i tożsamości kulturowej. Szczególnie ważnym dla ruchu wydarzeniem było przywrócenie tak zwanych Jocs Florals (Igrzysk Kwiatowych), wywodzących się ze średniowiecznej tradycji turniejów

34 J.M. Fradera, Cultural Nacional en una Societat Dividida, Barcelona 1992, s. 89.

35 W Katalonii na popularności zyskały założenia romantycznej koncepcji Volk niemieckiego filozofa Johanna Gottfrieda Herdera. Głównym elementem jego myśli jest „szczególność” — to znaczy przekonanie, że człowiek „,nie może się zdefiniować inaczej niż w odniesieniu do konkretnej religii, określonego języka, wspólnego wzorca odczuwania”. Grupa podzielająca te cechy kulturowe stanowiła Volk. Kolejnym założeniem niemieckiego filozofa było przekonanie, że każdy Volk ma ducha (geist — boską esencję), który nie mógł się mieszać z innymi, ponieważ było to nienaturalne i fałszywe. Herder definiował Volk jako organizm, którego istotą był jego „narodowy charakter", zdefiniowany przez jego fizyczne i historyczne otoczenie i ustanowiony przez Boga. Człowiek nie mógł bez ograniczeń myśleć w wielu formach i językach — urodził się tylko z jednym. Zob. J.R. Llobera, The idea of Volksgeist in the formation of Catalan nationalist ideology, „Ethnic and Racial Studies" 1983, nr 6, s. 332; J.H. Elliott, The Revolt of Catalans, Cambridge 1963, s. 19; A. Balcells, Historia de Catalunya, Barcelona 2009.

36 D. Conversi, The Basques, the Catalans, and Spain. Alternative Routes to Nationalist Mobilisation, London 1997, s. 14-15; J.R. Llobera, op. cit., s. 340. 
poetyckich. Miały one stanowić święto, podczas którego propagowano wspólne elementy tożsamości: języka, historii, literatury i mentalności. Jedną z kluczowych postaci Igrzysk Kwiatowych i całego ruchu Renaixença był kapłan-poeta Jacint Verdaguer - jego twórczość połączyła klasy elity burżuazyjnej i wiejskie elity ${ }^{37}$.

$\mathrm{W}$ trakcie prac nad ideologicznymi podstawami ruchu powstał nowy termin, Volk, który był intelektualną odpowiedzią na polityczną bezsilność Katalonii, wciąż widoczną pomimo wzrastającego dynamizmu gospodarczego. Ponieważ burżuazja nie mogła apelować do wiejskich elit o pomoc w ochronie i rozwoju gospodarki Katalonii, należało wypracować wspólną płaszczyznę porozumienia. Jednocześnie termin Volk jako figura retoryczna był tutaj szczególnie przydatny, ponieważ jego religijny wydźwięk odpowiadał potrzebom mieszkańców terenów wiejskich. Według Josepa Llobery wynika to z faktu, że „rozumowanie Volk było »boskim prawem: duch kataloński był stworzeniem Bożym, a zachowanie go było zgodne z wolą Bożą «" ${ }^{38}$. Ponadto wspólna idea sprzyjała budowaniu solidarności społecznej przeciwko naciskom ze strony państwa hiszpańskiego. Główną wartością dla wiejskiej elity była obrona odrębności narodowej Katalonii ${ }^{39}$.

Burżuazja i muntanyesos zjednoczyły się w ramach Renaixença, ponieważ obie te klasy łączył wspólny wróg — hiszpański rząd centralny. Jednakowoż należy podkreślić, że kataloński romantyczny nacjonalizm przez większość XIX wieku był zaledwie tematem społecznym. Chociaż przewaga burżuazji w katalońskiej polityce pozwoliła na spopularyzowanie ideałów romantycznych, to faktem jest, że do 1882 roku nie pojawiły się partie regionalne ani nacjonalistyczne ${ }^{40}$.

Natomiast $\mathrm{w}$ pozostałych regionach katalońscy przemysłowcy byli postrzegani jako „nieudana klasa hegemoniczna”, która „zjednoczyła się w poparciu dla katolicyzmu, zapewniając wyraźne wsparcie finansowe dla inicjatyw politycznych i kulturalnych" Jedną z tych inicjatyw było założenie pierwszej katalońskiej partii nacjonalistycznej — Centre Català — w 1882 roku przez Valentiego Almiralla lewicowego radykała. W ten sposób połączyły się romantyczny kataloński nacjonalizm i burżuazyjne interesy ${ }^{41}$.

Almirall twierdził, że każdy, kto pragnie posiadać wpływ na sprawy publiczne, powinien być definiowany jako polityk, ponieważ tylko poprzez politykę można zmienić istniejący stan rzeczy. W swoim programie politycznym przejął założenia romantycznych filozofów Renaixença, uznając centralną pozycję katalońskiego Volk, ale dodawał, że jedynym sposobem na jego zachowanie i kultywo-

37 J.M. Fradera, op. cit., s. 25.

38 J.R. Llobera, Foundations of National Identity. From Catalonia to Europe, New York 2004, s. 66.

39 J.R. Llobera, The idea of Volksgeist..., s. 332.

40 R. de Abadal y Vinyals, Dels visigots als catalans. La Hispània visigòtica i la Catalunya carolíngia, „La Formació de la Catalunya Independent” 62, 1969-1970, nr 2, s. 140; idem, El domini carolingi a Catalunya, t. 1, Barcelona 1986, s. 55-56.

41 D. Conversi, op. cit., s. 17-18. 
wanie jest szerokie działanie polityczne, a nie ograniczona promocja kultury Katalonii. Dla niego teoria jedynie nadawała zarys idei Volk i stworzyła świadomość narodową. Działacz ten twierdził też, że „aby zachować ideały romantycznej duszy narodowej, katalońscy literaci powinni zrobić coś więcej niż tylko doskonalić już istniejącą teorię odrodzenia kulturowego, należy działać w kierunku jej urzeczywistnienia w działaniu". Ideologia polityczna Almiralla popularność zyskała głównie wśród klasy burżuazji przemysłowej, ale zaangażowanie widoczne było także wśród elit z innych warstw społecznych. Partię Centre Català poparli wiejscy intelektualiści, mutanyesos, artyści i konserwatywni prawnicy ${ }^{42}$. Na początku lat osiemdziesiątych XIX wieku burżuazja katalońska uznała, że wyczerpała już wszelkie możliwości uczestnictwa w polityce hiszpańskiej i realizacji swoich postulatów na poziomie centralnym i musi zintensyfikować swoją działalność na obszarze regionu ${ }^{43}$.

Oznacza to, że ideologia katalońskiego Volk w rzeczywistości była próbą „pogodzenia tradycjonalistycznego (muntanyesos) i progresywnego (burżuazja) elementu wewnątrz katalonizmu, połączona postulatami obrony katalońskich interesów gospodarczych" 44 . Aby odwołać się do tych różnorodnych grup, Almirall musiał przeprowadzić akcję równoważącą. Głównym osiągnięciem Centre Català było stworzenie manifestu zatytułowanego Memorial de Greuges. Dokument ten, przekazany królowi Alfonsowi XII w 1885 roku, był pierwszą oficjalną i zorganizowaną akcją protestacyjną partii katalońskiej przeciwko władzy centralnej. Była to także bezpośrednia próba wpłynięcia na rząd hiszpański poprzez otwarty dialog. Jak widać, Katalończycy stworzyli długoletnią praktykę walki o swoją tożsamość w sposób pokojowy, oparty na działaniach o charakterze demokratycznym i dialogu, nie zaś na agresji i użyciu siły ${ }^{45}$.

Kolejnym elementem politycznej strategii Valentíego Almiralla było założenie w 1879 roku pierwszego dziennika w języku katalońskim — „Diari Català” — i dwa lata później magazynu kulturalnego „L’Avens”. Własne media pozwalały rozszerzyć strefy wpływu ideologii katalonizmu poza centrum regionu, czyli Barceloną. W 1880 roku odbył się pierwszy Kongres Kataloński, którego efektami były opracowanie dokumentu końcowego, broniącego prawa katalońskiego przed ograniczeniami władzy centralnej, i założenie organizacji politycznej Centre Català ${ }^{46}$. W swoim dziele Lo Catalanisme, opublikowanym w 1886 roku, Almirall nakreślił założenia przejścia od regionalizmu do nacjonalizmu opartego na idei państwa fe-

42 Ibidem, s. 16.

43 J.R. Llobera, The idea of Volksgeist..., s. 332-350.

44 Ibidem, s. 18.

$45 \mathrm{Ch}$. Kark, From parlor to politics. Catalan romantic nationalism as a bourgeois political instrument, „LL Journal” 2, 2015, nr 2, s. 8.

46 Było to ugrupowanie, które miało jednoczyć Katalończyków o różnych przekonaniach politycznych wokół wspólnej ideologii nacjonalizmu regionalnego. Zob. J. Llorens i Vila, La unió catalanista. 1891-1904 (Episodis de la història), Barcelona 1991, s. 11. 
deralnego. Dzieło to zawierało pierwszy wyraźny program kataloński. Jednakże w 1887 roku większość członków prawego skrzydła partii odeszła z niej, tworząc oddzielną Lliga de Catalunya. Nowa organizacja wkrótce stała się znaczącą siłą w polityce katalońskiej ${ }^{47}$.

$\mathrm{Na}$ wczesnym etapie swojego istnienia ruch regionalistyczny nie miał na celu oddzielenia regionu od Hiszpanii, ale raczej próbował wypracować narzędzia nacisku na działania rządu centralnego wobec Katalonii oraz wysyłać swoich przedstawicieli do Kongresu i Senatu w Madrycie. Jednak starania katalońskiej burżuazji o zapewnienie wpływowych pozycji w hiszpańskim rządzie stanowym zostały udaremnione z powodu różnic ideologicznych. Centralistyczna oligarchia ziemska, zdominowana przez politykę Madrytu, była niechętnie nastawiona i niezdolna do modernizacji Hiszpanii. Stało się jasne, że żądania szerokiej autonomii Katalonii nigdy nie zostaną spełnione. Uprawnienia, których przyznanie władzom regionu postulowano, obejmowałyby opodatkowanie, monety i kontrolę nad ustawodawstwem cywilnym, karnym i handlowym. Chciano stworzenia niezależnej regionalnej armii i sił policyjnych oraz zarządzanego na poziomie lokalnym systemu edukacji. Zasadniczo były to żądania pozwalające na skonstruowanie katalońskiego rządu federalnego. Przywódcy Unió Catalanista ${ }^{48}$ zdawali sobie sprawę, że pomysły te nie zakorzeniły się jeszcze w całym społeczeństwie katalońskim. W związku z tym w 1892 roku sformułowano program polityczny ugrupowania, Bases de Manresa, który był manifestem określającym długofalowe cele katalonizmu politycznego, jakie należałoby osiągnąć w nadchodzących latach; ponadto zawierał spis wszystkich wysuwanych wcześniej wobec rządu centralnego postulatów ${ }^{49}$.

Członkowie Centre Català opracowali własny program, aby zjednoczyć w jej ramach odmienne grupy społeczne, które miały zróżnicowane spojrzenia na zadania organizacji. Burżuazja miejska chciała przede wszystkim zapewnienia sobie protekcjonizmu gospodarczego. Środkiem realizacji tego celu było zachowanie katalońskiego prawa cywilnego, które Madryt chciał znieść. Natomiast ograniczenie niezależności katalońskiego systemu prawnego, któremu sprzeciwiała się grupa katalońskich prawników i muntanyesos, przyczyniło się do udzielenia przez te grupy, postrzegające Centre Català jako szansę na odzyskanie odebranych im praw, poparcia dla tej organizacji. Ich dobrobyt ekonomiczny zależał bowiem od autonomii katalońskiego prawa cywilnego. Innym ważnym czynnikiem politycznego zaangażowania muntanyesos była ochrona pamięci historycznej o utraconej

47 V. Almirall, Lo catalanisme. Motius que el legitimen fonaments cientifics i solucions pràctiques, Barcelona 2013, s. 223.

48 Konserwatywna organizacja polityczna, która została założona w 1891 roku w celu zjednoczenia związków zawodowych i stowarzyszeń sprzeciwiających się ograniczaniu katalońskiego prawa cywilnego przez rząd centralny. Założyciele ugrupowania i członkowie jego zarządu: Lluís Domènech i Montaner, Pau Font de Rubinat, Enric Prat de la Riba, Joaquim Vayreda i Pau Colomer. Zob. J. Llorens i Vila, op. cit., s. 21.

49 J.R. Llobera, op. cit., s. 60, 126-127. 
wolności Katalonii oraz chęć odbudowy tożsamości etnicznej narodu katalońskiego w ramach odrodzenia kulturowego ${ }^{50}$.

Przywódcy Unió Catalanista ${ }^{51}$ spotkali się w 1892 roku w Manresie i opracowali kolejny dokument, Bases de Manresa ${ }^{52}$. Zawarte w nim zapisy były znacznie bardziej radykalne niż postulaty wcześniejszego Memorial de Greuges ${ }^{53}$. Formalnie żądano szerokiej politycznej autonomii dla Katalonii, zastąpienia narzuconego w 1833 roku sztucznego podziału terytorialnego i przywrócenie dawnego podziału na regiony ${ }^{54}$.

Na przełomie XIX i XX wieku ponownie powrócono do łagodniejszej wersji katalonizmu w ramach poszerzania kompetencji autonomistycznych. W 1914 roku katalońskie elity wystosowały wobec rządu w Madrycie postulat połączenia czterech okręgów katalońskich — Barcelony, Tarragony, Girony i Lleidy — w organizację pod nazwą Mancomunitat de Catalunya ${ }^{55}$. Przewodzić jej miał prezydent Katalonii, Eric Prat de la Riba. Działacz ten, wspólnie z Francescem Cambó, przywódcą katalońskich deputowanych w Madrycie, zaczął lobbować w rządzie centralnym w tej sprawie. Nie żądali oni przy tym poszerzenia kompetencji władz Katalonii o żadne dodatkowe uprawnienia. Politycy ci ograniczyli się do uzyskania zgody na stworzenie jednej wspólnej instytucji, tak aby cztery katalońskie prowincje mogły ze sobą współpracować i dzielić się swoimi zasobami w celu zwiększenia wydajności gospodarczej regionu. De la Riba oraz Cambó podkreślali, że ich projekt ma charakter symboliczny i stanowi próbę odtworzenia Katalonii jako jednostki administracyjnej. Katalońscy politycy zakładali likwidację przestarzałego systemu prowincji i tradycyjnych comarców, funkcjonujących w społecznej świadomości jako obce struktury, które zostały przymusowo narzucone przez Madryt w 1833 roku $^{56}$.

50 Ibidem, s.18.

51 J. Linz, Early State-Building and Late Peripheral Nationalisms Against the State. The Case of Spain. Building States and Nations. Analyses by Region, red. S.N. Eisenstadt, S. Rokkan, Beverly Hills 1973, s. 62.

52 Dokument ten został przyjęty 27 marca i stanowił wstęp do opracowania Konstytucji Regionalnej. Zakładał on stworzenie szerokiej autonomii, nie zawierał natomiast postulatów niepodległościowych. Zob. A. Balcells, Catalan Nationalism. Past and Present, New York 1996, s. 36; J.M. Figueres, V. Almirall, Forjador del Catalanisme Politic, Barcelona 1990, s. 174.

53 Był to memoriał przygotowany w 1885 roku ,w obronie moralnych i materialnych interesów Katalonii”, wysłany do króla Alfonsa XII. Głównym inicjatorem stworzenia tego pisma był Valentí Almirall. Memoriał jest uważany za pierwszy skierowany do rządu centralnego polityczny akt Katalonii. Zob. F. Cabana, Memorial de greuges, „El Punt Avui” 2012, nr 27, s. 23.

54 J. de Puig i Oliver, J. Rodó Rodà, F. Comas Closas, 125 anys de les Bases de Manresa (18922017). Memòria del programa i miscel-lània sobre la Manresa de fa 125 anys, Barcelona 2019, s. 11.

55 Było to nowe porozumienie polityczne regionów, którego najważniejszą funkcją było koordynowanie stosunków międzynarodowych tworzących ją organizmów. Zob. A. Alland, Catalunya, One Nation, Two States. An Ethnographic Study of Nonviolent Resistance to Assimilation, New York 2006, s. 47.

56 A. Alland, op. cit., s. 47. 
Rząd centralny odrzucił projekt i choć katalońscy przywódcy wyrażali wolę demokratycznego dialogu, odpowiedział agresywnymi działaniami. Nastąpiło pięć dni dewastacji, ataków i przemocy — znanych w historii jako Setmana Tràgica $^{57}$ (Tragiczny Tydzień). Skutkiem tego rodzaju strategii władzy madryckiej było wzmocnienie opozycyjnych partii katalońskich w rządzie hiszpańskim. Idea zjednoczenia prowincji zyskiwała szerokie poparcie w całym społeczeństwie katalońskim. Na początku 1913 roku w katalońskich miejscowościach Falset, Cornudella de Montsant i Santa Coloma de Queralt zorganizowano demonstracje, a 1073 katalońskich Ajuntaments (rad miejskich) zostało poddanych badaniu na poparcie Prawa Mancomunidades ${ }^{58}$. Dnia 27 października tego samego roku na ulicach Barcelony odbyła się masowa demonstracja z udziałem 60 tysięcy osób ${ }^{59}$.

Ostatecznie Mancomunitat została utworzona 6 kwietnia 1914 roku podczas uroczystości w Palau de la Generalitat; wówczas też Eric Prat de la Riba został jednogłośnie wybrany na pierwszego prezydenta nowej organizacji. Jednak jej znaczenie w polityce hiszpańskiej pozostało głównie symboliczne ${ }^{60}$.

W kolejnych latach tendencje autonomiczne uległy zahamowaniu w wyniku zmian politycznych w Hiszpanii. 13 września 1923 roku Miguel Primo de Rivera ogłosił w Madrycie powstanie dyktatury. Mimo że początkowo wspierał on katalońską burżuazję, jednocześnie zwalczał ruchy nacjonalistyczne i związkowe, aż ostatecznie rozwiązał Mancomunitat i zakazał całkowicie używania symboli katalońskich ${ }^{61}$.

Dopiero po upadku dyktatury Prima de Rivery, do którego przyczynił się kryzys gospodarczy, doszło do zawarcia porozumienia pomiędzy reprezentantami partii republikańskich z Kastylii, Galicji i Katalonii, znanego jako pakt z San

57 Tak zwane powstanie barcelońskie, które toczyło się w okresie od 26 lipca do 2 sierpnia 1909 roku. Tym mianem określa się ciąg krwawych starć związków robotniczych Barcelony i innych miast Katalonii z siłami wojskowymi rządu centralnego. Powodem konfliktu było poparcie dla sił republikańskich, socjalistycznych i anarchistycznych, opozycyjnych wobec reżimu prawicowego. Bezpośrednią przyczyną był z kolei dekret premiera Antonio Maury, ogłaszający obowiązek poboru do armii hiszpańskiej i walki w wojnie z Marokiem. Zob. R. Corts i Blay, La Setmana Tràgica de 1909. L'Arxiu Secret Vaticà, L'Abadia de Montserrat 2009, s. 23, 27-28.

58 Przy 1016 głosów za, reprezentujących 96\% populacji Katalonii, Lliga Regionalista zorganizowała Zgromadzenie Katalońskie z przedstawicielami wszystkich partii politycznych. Zob. F.X. Santamaria Balaguer, Prat De La Riba I La Institucionalització D'un Model De Cultura Catalana. L'obra Cultural I Pedagògica, Barcelona 2010. Ley de Mancomunidades było prawem wprowadzonym na mocy dekretu królewskiego z dnia 18 grudnia, stanowiącym o decentralizacji podziału administracyjnego. Jego wprowadzenie miało umożliwić tworzenie wspólnot jednostek administracyjnych niższego szczebla w celu efektywniejszego ich funkcjonowania. Miały być formą samorządu bez uprawnień politycznych. Zob. Á. Domínguez, J. Miguel, Cuánto más grande, mejor. La diputación leonesa y las Mancomunidades, „Estudios Humanísticos. Historia” 2007, nr 6, s. 227.

59 R. Corts i Blay, op. cit., s. 27.

60 J. Casassas i Ymbert, 1914, centenari de la Mancomunitat de Catalunya i la significació del bicentenari de 1714 en la seva perspectiva històrica: discurs llegit en la sessió inaugural del curs 2013-2014, Barcelona 2013, s. 37-38.

61 G. Tortella, Catalonia in Spain. History and Myth, Cham 2017, s. 155-156. 
Sebastian ${ }^{62}$. Stanowiło ono fundament nowej konstytucji, w ramach której Katalonia zyskiwała na nowo autonomię w ramach republiki. Stworzono Generalitat de Catalunya, napisano też projekt nowego statutu, który zyskał znaczące poparcie w referendum. Następnie dokument został zatwierdzony przez hiszpańskie Kortezy w dniu 9 września 1932 roku jako Statut Autonomii Katalonii. 6 października 1934 roku ówczesny prezydent Generalitat Lluís Companys proklamował powstanie Republiki Katalońskiej jako niezależnego państwa ${ }^{63}$.

W listopadzie 1933 roku wybory parlamentarne w Hiszpanii wygrała prawicowa koalicja CEDA ${ }^{64}$ José Marii Gil-Roblesa, w skład której weszli również antykatalońscy radykalni republikanie Alejandra Lerroux. Nowy rząd hiszpański zakwestionował reformy edukacyjne i rolne w całej Hiszpanii, ale, co istotniejsze, otwarcie sprzeciwił się autonomii Katalonii i jej prawu do posiadania własnego Generalitat ${ }^{65}$.

2 października 1934 roku w Hiszpanii ogłoszono strajk generalny przeciwko rządowi CEDA. Organizacja Aliança Obrera, lewicowy sojusz socjalistów, anarchistów, komunistów i Katalończyków, zorganizował 5 października masową demonstrację w Barcelonie, która stała się miejscem pokojowej okupacji. Akcja ta była nieformalnie wspierana przez Lluísa Companysa i Generalitat. Następnego popołudnia liczna manifestacja pod przewodnictwem Aliança Obrera udała się pod budynki rządowe, żądając proklamacji odrębnej republiki katalońskiej66.

W okresie od 17 czerwca 1936 do 1 kwietnia 1939 roku Hiszpanią wstrząsała brutalna wojna domowa. Katalonia opowiedziała się w niej po stronie Republiki przeciwko rebelianckim grupom prawicowym pod dowództwem generała Francisca Franco. Katalońskie władze regionalne udzieliły azylu politycznego rządowi republikańskiemu. Po zwycięstwie frankistów autonomia Katalonii została zniesiona, podobnie jak wszystkie dotychczasowe przywileje autonomii regionu. Zakazano używania języka i symboli katalońskich, które miały zostać zastąpione uniwersalną kulturą hiszpańską, a za publiczne łamanie tego zakazu groziły surowe kary i represje. Kiedy w Katalonii wybuchły masowe protesty i demonstra-

${ }^{62}$ Spotkanie partii republikańskich, zainicjowane przez Alianza Republicana, które odbyło się 17 sierpnia 1930 roku. Jego celem było zniesienie monarchii i zastąpienie jej II Republiką. Zob. J. Santos, La Constitución de 1931, Madryt 2009, s. 25.

63 G. Tortella, op. cit., s. 158.

64 Confederación Española de Derechas Autónomas - federacja katolickich i konserwatywnych partii politycznych, założona 4 marca 1933 roku. Jej głównymi twórcami byli Ángel Herrera Oria, założyciel i redaktor naczelny dziennika „El Debate” (Debata), i José María Gil-Robles, późniejszy lider CEDA. Programowo opowiadała się ona za wprowadzeniem ustroju totalitarnego. Ideologicznie była związana z nurtem klerykalno-konserwatywnym, sympatyzowała z faszyzmem i nazizmem. Zob. P. Preston, Coming of the Spanish Civil War, Routledge 2003, s. 65.

65 Ibidem.

66 Ibidem, s. 26 
cje w obronie praw kulturalnych i politycznych, rząd centralny wysłał przeciwko protestującym wojsko i policję ${ }^{67}$.

Mimo dotkliwych represji opór Katalończyków wobec Franco nigdy całkowicie nie zaniknął, a grupy partyzanckie ukrywały się w Pirenejach. Pierwsze tajne katalońskie organizacje antyfrankistowskie wywodziły się, co zaskakujące, z Kościoła katolickiego, którego uprzywilejowana wobec dyktatury pozycja ułatwiała konspirację. W latach sześćdziesiątych XX wieku na szeroką skalę zaczęły powstawać nielegalne związki zawodowe, grupy studenckie i stowarzyszenia mieszkańców. W 1971 roku, wraz ze schyłkiem epoki frankizmu, uformowała się Assemblea de Catalunya czyli rozległy sojusz katalońskich grup politycznych i religijnych. Co interesujące, Kościół katolicki nadal był siłą napędową katalońskiej opozycji, a kościoły i klasztory stały się bezpiecznymi schronieniami dla lokalnej partyzantki. W ten sposób ukształtowała się niespotykana dotąd współpraca między katolickimi konserwatystami a radykalną lewicą. Grupy te miały wspólne interesy zarówno na polu kwestii społecznych, jak i obrony języka. Siła katalońskiego sprzeciwu wobec Franco widoczna była właśnie w jego szerokich wpływach we wszystkich sferach społeczeństwa katalońskiego ${ }^{68}$.

Pierwszą otwartą akcją oporu był strajk tramwajowy w 1951 roku, tak zwana Huelga de tranvías de Barcelona de 1951. Wzrost cen biletów spowodował, że przejazdy transportem zbiorowym w Barcelonie stały się znacznie droższe niż w Madrycie. Opozycja zorganizowała bojkot komunikacji publicznej. W trakcie „ostatniej bitwy pokolenia, które przegrało wojnę domową" cała populacja Barcelony obserwowała strajk transportowy. Tramwaje i autobusy kursowały całkowicie puste przez ponad dwa tygodnie. Skuteczność bojkotu była widoczna w pierwszą sobotę po jego rozpoczęciu, kiedy odbywał się mecz FC Barcelona. Futbol zawsze był ważnym elementem tożsamości katalońskiej, a stadion Camp Nou i klub piłkarski odgrywały ważną rolę w historii katalonizmu. Fani FC Barcelony na znak protestu zignorowali tramwaje i odbyli czterdziestominutową pieszą podróż na Camp Nou. Wspieranie klubu było również sposobem na integrację mas hiszpańskojęzycznych imigrantów, którzy przybywali do miasta od lat pięćdziesiątych XX wieku. Strajk tramwajowy w 1951 roku był kluczowym momentem w dziejach oporu Katalończyków wobec reżimu Franco. Następnie protest przerodził się w strajk generalny związków zawodowych w całej Barcelonie (wzięło w nim udział około 300 tysięcy robotników). W jego efekcie doszło do brutalnych starć, w wyniku których zginęło wielu protestujących ${ }^{69}$.

Kataloński ruch oporu rozwijał się w latach sześćdziesiątych i wczesnych siedemdziesiątych, głównie dzięki zwiększeniu zasięgu telewizji i rozwojowi maso-

67 C. Güell Ampuero, The Failure of Catalanist Opposition to Franco (1939-1950), London 2006, s 45-46.

68 Ch. Ealham, Class, Culture and Conflict in Barcelona, 1898-1937, Routledge 2004, s. 138.

69 A. Cazorla Sánchez, Las políticas de la victoria. La consolidación del Nuevo Estado franquista, Madrid 2000, s. 185. 
wej turystyki międzynarodowej. Częściowe otwarcie społeczeństwa hiszpańskiego, mimo nadal obecnych brutalnych represji i cenzury, pobudzało obywateli do walki o swoje prawa. W pierwszej połowie lat sześćdziesiątych XX wieku Kościół i społeczeństwo obywatelskie ponownie zjednoczyły się przeciwko reżimowi. Na początku 1966 roku powstał oficjalny związek studentów, Sindicato Español Universitario, w efekcie którego działalności zamknięto Wydział Ekonomiczny uniwersytetu w Barcelonie. W marcu 1966 roku pięciuset delegatów studenckich, profesorów i intelektualistów spotkało się w celu utworzenia nowej, niezależnej organizacji, Sindicat Democràtic d'Estudiant de la Universitat de Barcelona (SDEUB, Demokratyczny Związkek Studentów Uniwersytetu w Barcelonie) ${ }^{70}$. Wydarzenie to stało się znane jako Caputxinada ${ }^{71}$ — nazwa ta pochodzi od miejsca, w którym to się stało, czyli klasztoru kapucynów na przedmieściach Sarrià w Barcelonie. Podczas wspomnianego spotkania doszło do ataku wojsk generała Franco na klasztor i jego późniejszego oblężenia. Efektem wspomnianych rozmów było powstanie platformy opozycyjnej — La Taula Rodona — która stała się fundamentem Asamblea de Cataluña. SDEUB uzyskał bardzo wysokie poparcie wśród studentów $-20 \% \mathrm{z}$ nich aktywnie się angażowało w jej działalność ${ }^{72}$. Rok akademicki 1966/1967 był okresem intensywnej działalności politycznej i kulturalnej wśród katalońskich żaków. Reżim zareagował wyrzuceniem z uczelni ponad stu studentów i profesorów oraz zawieszeniem na cały rok akademicki wszystkich rekrutacji na uniwersytet w Barcelonie. Pomimo represji wiadomości o serii europejskich buntów studenckich w maju 1968 roku wzmocniły ideały katalonizmu w lokalnych szkołach wyższych ${ }^{73}$.

Okres dyktatury frankistowskiej był również czasem rozwoju ruchów robotniczych, stanowiących główną oś opozycji politycznej. Ta skupiała się głównie wokół dwóch ośrodków: założonego w 1964 roku tajnego związku Komisji Robotniczych (Comisiones Obreras - $\mathrm{CCOO}^{74}$ ) i utworzonego siedem lat później Zgromadzenia Katalońskiego (Assemblea de Catalunya - $\mathrm{AC}^{75}$ ), które zrzeszało mniejsze organizacje opozycyjne z całego regionu, cechujące się różnorodnymi profilami politycznymi. Ich aktywność w postaci strajków i manifestacji była wi-

70 J.M. Colomer, Els estudiants de Barcelona sota el franquisme, „Curial” 1-2, 1978, s. 217.

71 C. Fons i Duocastella, La Caputxinada. Frares compromesos amb el país i la llibertat, Barcelona 2016, s. 32, 56, 115-116.

72 Ibidem.

73 A. Dowling, The Rise of Catalan Independence. Spain's Territorial Crisis, Routledge 2017, s. $27,53,110$.

74 R.M. Fishman, Working-Class Organization and the Return to Democracy in Spain, Ithaca 2019 , s. 37-38.

${ }^{75} \mathrm{~W}$ jej skład weszły partie i ugrupowania prezentujące szeroki wachlarz poglądów, między innymi socjalistyczne, komunistyczne, partia CDC Jordiego Puyola, ugrupowania chrześcijańsko-demokratyczne, a także szereg organizacji niezależnych: studenckich, naukowych, obywatelskich, religijnych. Opozycja zjednoczyła się ponad podziałami, aby przeciwstawić się reżimowi frankistowskiemu. Zob. G. Tortella, op. cit., s. 177. 
doczna od początku wprowadzenia dyktatury. Działacze Assemblea ${ }^{76} \mathrm{w}$ swoim programie deklarowali walkę o amnestię, wolność i uzyskanie przez Katalonię autonomii; ponadto, będąc nieformalnym centrum opozycji, starali się koordynować z organizacjami antyfrankistowskimi z całego kraju wspólne działania. Utworzenie takiej bezprecedensowo szerokiej koalicji sił opozycyjnych stało się jednym z kluczowych momentów w historii nacjonalizmu katalońskiego. Inicjatywa zapoczątkowana przez komunistów zjednoczyła przeciwników dyktatury i wkrótce grupowała wokół siebie większość katalońskich partii politycznych, związków zawodowych i organizacji obywatelskich. Po śmierci generała Franco w lipcu 1976 roku miała miejsce pierwsza duża akcja demonstracyjna, Marxa de la Llibertat, marsz pod hasłem „Wolność, amnestia i statut autonomii”. Akcja ta miała być całkowicie pokojowa. Jej plan zakładał rozmowy i spotkania w różnych wioskach w trakcie marszu sześciu kolumn z l'Escali, Oliany, Esterri d’Àneu, la Sénii, Girony, Guardamar del Segura do Barcelony. Marsz miał się zakończyć pokojową demonstracją podczas katalońskiego święta narodowego, 11 września, w klasztorze Poblet. Reakcja reżimu, na którego czele stał wówczas Arias Navarro, i użycie siły wobec pokojowo protestujących zostało powszechnie skrytykowane. Wspomniane manifestacje stały się siłą napędową w utrzymaniu wspólnego frontu inicjatyw opozycyjnych. Assemblea rozpadła się, osiągnąwszy swój cel, gdy pod koniec lat siedemdziesiątych dokonała się przemiana ustrojowa w Hiszpanii ${ }^{77}$.

Po śmierci generała Franco w 1975 roku w kraju przywrócono monarchię, a na tronie zasiadł król Juan Carlos I, wyznaczony przez dyktatora na jego następcę. Władca jednak opowiedział się za zmianą ustroju i transformacją na system demokratyczny, wsparł też organizację wolnych wyborów w 1977 roku i stworzenie nowej konstytucji rok później. W ramach zapisów ustawy zasadniczej Katalonia odzyskała częściową samorządność ${ }^{78}$.

Kataloński ruch niepodległościowy zorganizowany w ramach formalnych struktur politycznych powstał de facto w 1922 roku, kiedy to Francisco Maciá założył partię Estat Catalá (Państwo Katalońskie) ${ }^{79}$. W 1931 roku Estat Catalá i inne partie utworzyły koalicję Esquerra Republicana de Catalunya - ERC (Republikańska Lewica Katalonii). Maciá proklamował Republikę Katalońską, a następnie zaakceptował koncepcję autonomii w ramach państwa hiszpańskiego, wynegocjowaną w porozumieniu z przywódcami II Republiki Hiszpańskiej. Niezależność Katalonii została zniesiona podczas dyktatury frankistowskiej i dopiero po jej upadku w 1975 roku możliwe było wznowienie politycznej działalności ruchu

76 Głównymi działaczami ugrupowania byli: Jordi Puyol, Josep Andreu i Abelló, Josep-Lluís Carod-Rovira, Xavier Folch.

77 A. Balcells, Catalan Nationalism..., s. 167.

78 J.H. Elliott, Scots and Catalans. Union and Disunion, New Haven 2018, s. 227.

79 J. Miravitlles, Critica del 6 d'octubre, [w:] Estat Catalá. The Strategies of separation and revolution of Catalan Radical Nationalism (1919-1933), red. E. Ucelay de Cal, New York 1979, s. 541-542. 
na rzecz autonomii regionu. Trzeba jednak podkreślić, że ówczesne projekty polityczne nie odwoływały się do idei niepodległości ${ }^{80}$.

Po śmierci generała Franco w Katalonii nastał chaos i rozpoczęła się rywalizacja o władzę polityczną. Szkieletem ruchu nadal była Assemblea de Catalunya. Należy zaznaczyć, że mimo znacznego wzrostu liczby strajków i pikiet ich charakter pozostał pokojowy. Po raz kolejny ważną rolę odegrały grupy religijne, między innymi Pax Christi. Organizacja ta zorganizowała manifestację Marxa de la Llibertat lub March for Freedom ${ }^{81}$.

Główne partie katalońskie utworzyły Consell de Forces Polítiques de Catalunya (Radę Sił Politycznych Katalonii) $^{82}$, aby wspólnie negocjować odbudowę instytucji katalońskich. Organ ten od samego początku utrzymywał kontakt z Josepem Tarradellasem, przewodniczącym Generalitat na uchodźstwie. Jesień 1977 roku była ważnym momentem dla ruchu autonomistycznego. 11 września 1977 roku, w dniu najważniejszego święta narodowego Katalonii — La Diada, ponad milion Katalończyków wzywających do „wolności, amnestii i statutu autonomii” uczestniczyło w największej demonstracji w powojennej Europie. La Diada z 1977 roku stała się sygnałem dla władz w Madrycie, że kataloński ruch nacjonalistyczny jest zdolny do skutecznego działania. 29 września rząd uchylił francuską ustawę znoszącą instytucje katalońskie, przywrócono również tymczasowy Generalitat ${ }^{83}$.

W 1978 roku weszła w życie nowa konstytucja, która wprowadziła ustrój demokratyczny. W ramach jej zapisów gwarantowano „niepodzielną jedność Narodu hiszpańskiego”, ale uznano przy tym „prawo do autonomii narodowości i regionów, które ją tworzą". Katalońskie partie niepodległościowe zgłosiły sprzeciw, argumentując, że ustawa zasadnicza stoi w sprzeczności z katalońskim prawem do samostanowienia. W efekcie utworzyły one Comitè Català Contra la Constitució Espanyola (Kataloński Komitet Przeciwko Konstytucji) ${ }^{84}$. Jednak konstytucja została zatwierdzona przez ogólnokrajowe referendum większością 88\% głosów, a w samej Katalonii głos „za” oddało 90\% mieszkańców ${ }^{85}$.

W 1979 roku powstał projekt statutu Autonomii Katalońskiej, który został zatwierdzony po poparciu go przez $88 \%$ Katalończyków. Tym samym grupy niepod-

80 S.L. Greer, Nationalism and Self-Government. The Politics of Autonomy in Scotland and Catalonia, Albany 2012, s. 93-94.

81 R. Aracil Martí, Memòria de la transició a Espanya i a Catalunya. Els joves de la transició, Barcelona 2000, s. 205-206.

82 M. Guibernau, Catalan Nationalism: Francoism, Transition and Democracy, Routledge 2004, s. 134

83 D. Venteo, Barcelona. A Historical Guide to the Contemporary City, Barcelona 2014, s. 213, 215, 228; J.R. Llobera, Foundations of National Identity..., s. 107.

84 P. Pagès i Blanch, La transició democràtica als Països Catalans. Història i memòria, València 2011, s. 250-251; J. Lluch, Visions of Sovereignty. Nationalism and Accommodation in Multinational Democracies, Philadelphia 2014, s. 52-53.

${ }^{85}$ X. Cuadras Morató, Catalonia. A New Independent State in Europe? A Debate on Secession within the European Union, Routledge 2016, s. 95, 102. 
ległościowe i skrajnie separatystyczne uległy zanikowi lub marginalizacji. Powstałą lukę próbowały zapełnić radykalne grupy bojowników, takie jak Tierra Lliure (TLL), ale bez większych sukcesów ${ }^{86}$.

W 1981 roku katalońscy intelektualiści wydali manifest opublikowany w formie listu, w którym domagano się zaprzestania dyskryminacji języka katalońskiego i kultury - Crida a la Solaritat en Defensa de la LLengua, la Cultura y la Nació Catalanes (,Wezwanie do solidarności w obronie języka katalońskiego, kultury i narodu") $)^{87}$.

Powstał wtedy nowy ruch, Crida, który zdołał zorganizować serię protestów. Początkowo był on organizacją kulturalną, ale szybko podjął działania polityczne, a wśród jego postulatów zaczęły się pojawiać idee niepodległościowe. Zgodnie z powtarzającym się w całej historii Katalonii wzorem początkowa aktywność w obronie katalońskiej kultury przekształciła się w działania o coraz bardziej politycznym charakterze. Mniejsze lewicowe partie katalońskie zgromadziły się w organizacji Terra Lliure ${ }^{88}$ (Wolna Kraina), która powstała w 1978 roku $^{89}$.

Działalność Cridy kończy etap pierwszy historycznego rozwoju ruchu nacjonalistycznego. W latach dziewięćdziesiątych i na początku XXI wieku katalonizm bazował głównie na działaniach w ramach formalnych struktur i partii. Nie był on również nastawiony na realizację celów twardego nacjonalizmu i separatyzmu i zamarł właściwie do 2010 roku, kiedy to nastąpiła reaktywacja współczesnego separatyzmu katalońskiego, rozumianego jako ruch obywatelski o politycznym charakterze, zorientowany na radykalne zerwanie więzi z państwem hiszpańskim.

\section{Zakończenie}

W artykule podjęto analizę historii nacjonalizmu katalońskiego przez pryzmat aktywności grup obywatelskich, partyzanckich, zrzeszeń i ruchów. Z niej wyprowadzić można wniosek, że akcje społecznego nieposłuszeństwa i aktywna

86 Terra Lliure stała się znana dzięki protestowi podczas masowego spotkania na stadionie Camp Nou w Barcelonie w 1981 roku. Organizacja uległa rozpadowi w 1995 roku. Po likwidacji wielu jej członków dołączyło do lewicowej partii katalońskiej Esquerra Republicana de Catalunya (ERC). TL była klasyfikowana jako organizacja terrorystyczna, mająca powiązania z baskijskimi terrorystami z ETA. Zob. R. Minder, The Struggle for Catalonia Rebel Politics in Spain, London 2017, s. 230; J. Busquets, La escalada del independentismo callan ha propiciado la escalada de violencia protagonizada por Terra Lliure, „El Pais” 17.04.1988, https://elpais.com/diario/1988/04/17/ espana/577231216_850215.html (dostęp: 2.12.2019); R. Vilaregut, Terra Lliure. La temptació armada a Catalunya, Columna 2004, s. 71, 223.

87 Daily Report. West Europe 1991, s. 33; zob. Nación y nacionalismos en la España de las autonomías, red. I. Sepúlveda Muñoz, Madrid 2018, s. 91-92; „Catalan Review” 16, 2002, s. 209.

88 R. Vilaregut, Terra Lliure..., s. 71, 223.

89 A. Balcells, op. cit., s. 211. 
rola katalońskich organizacji były widoczne już w początkowym okresie formowania się tożsamości katalońskiej w średniowieczu.

Już wtedy masowe bunty i manifestacje, oczywiście w swoich pierwotnych formach, stanowiły istotne narzędzia walki o przywileje i prawa regionu. Ruch protestu i oporu początkowo związany był ze stanem chłopskim, który walcząc o prawa do swoich ziem, poruszał także kwestie tożsamości regionalnej. W kolejnych wiekach idea nacjonalizmu katalońskiego (katalonizmu) zdobyła poparcie klas wyższych i elity intelektualnej. Dzięki temu zyskała bardziej określone ramy teoretyczne i konkretne cele w postaci ochrony języka i specyfiki kulturowej oraz historycznej regionu. Od XIX wieku ruch nacjonalistyczny ewoluował, ulegając postępującemu upolitycznieniu; jego postulaty oprócz kwestii językowych i tożsamości kulturowej dotyczyły też kwestii własnych praw i kompetencji, kształtowania lokalnej gospodarki, podziału administracyjnego regionu i odrębnych organów administracyjnych. Zaczęły powstawać organizacje polityczne i partie, które opracowały program ruchu i strategie budowania własnej autonomii.

Przeprowadzona w niniejszym artykule analiza wykazała, że społeczeństwo katalońskie samo kreuje zmiany, broni własnych wartości, tożsamości, i to jego wola polityczna powodowała powstawanie ruchów społecznych.

Ruch nacjonalistyczny ukształtował się jako odpowiedź na przemoc instytucjonalną stosowaną przez rząd madrycki do tłumienia wszelkich przejawów walki o prawa regionu. Były to nieproporcjonalnie ostre środki przymusu wymierzone przeciwko pokojowym akcjom demonstracyjnym i manifestacjom w przestrzeni publicznej. Niechęć do dialogu politycznego istotnie wpływała na radykalizację ruchu i zmianę postulatów od budowy wspólnego państwa federalnego do projektu stworzenia własnego, niepodległego państwa.

Niniejszy artykuł miał za zadanie wskazać, że zjawisko ruchów oporu przeciwko atakom na nacjonalizm kataloński należy interpretować jako element tradycyjnej tożsamości. Tym samym błędem jest przyjmowanie perspektywy traktującej współczesny ruch niepodległościowy jako chwilowego trendu o niewielkim wpływie na współczesną politykę Hiszpanii.

\section{Bibliografia}

de Abadal y Vinyals R., Dels visigots als catalans: La Hispània visigòtica i la Catalunya carolíngia, „La formació de la Catalunya independent” 62, 1969-1970, nr 2.

de Abadal y Vinyals R., El domini carolingi a Catalunya, t. 1, Barcelona 1986.

Alland A., Catalunya, One Nation, Two States. An Ethnographic Study of Nonviolent Resistance to Assimilation, New York 2006.

Almirall V., Lo catalanisme. Motius que el legitimen fonaments cientifics i solucions pràctiques, Barcelona 2013.

Aracil Martí R., Memòria de la transició a Espanya i a Catalunya. Els joves de la transició, Barcelona 2000. 
Balcells A., Catalan Nationalism. Past and Present, New York 1996.

Balcells A., Historia de Catalunya, Barcelona 2009.

Busquets J., La escalada del independentismo callan ha propiciado la escalada de violencia protagonizada por Terra Lliure, „El Pais” 17.04.1988, https://elpais.com/diario/1988/04/17/ espana/577231216_850215.html.

Cabana F., Memorial de greuges, „El Punt Avui” 2012, nr 27.

Cartas Acordadas Real Audiencia, Archivo de la Corona de Aragón, ACA, REAL AUDIENCIA, Registros, 6.

Casassas i Ymbert J., 1914, centenari de la Mancomunitat de Catalunya i la significació del bicentenari de 1714 en la seva perspectiva històrica: discurs llegit en la sessió inaugural del curs 2013-2014, Barcelona 2013.

Castells M., The City of the grassroots, Oakland 1983.

Castells M., The Power of Identity, Malden 2004.

Castells M., The Rise of the Network Society, Oxford 2000.

Castells M, Siła tożsamości, przeł. S. Szymański, Warszawa 2009.

„Catalan Review” 16, 2002.

Colomer J.M., Els estudiants de Barcelona sota el franquisme, „Curial” 1-2, 1978.

Conversi D., Language or race? The choice of core values in the development of Catalan and Basque nationalisms, „Ethnic and Racial Studies” 13, 1990.

Conversi, D., The Basques, the Catalans, and Spain. Alternative Routes to Nationalist Mobilisation, London 1997.

Corts i Blay R., La Setmana Tràgica de 1909. L'Arxiu Secret Vaticà, L'Abadia de Montserrat 2009.

Cuadras Morató X., Catalonia. A New Independent State in Europe? A Debate on Secession within the European Union, Routledge 2016.

Cumané y Fabrellas G., Fueros de Cataluña. Resúmen histórico-legal de los principales usages, constituciones, derechos y franquicias que se observan en el antiguo principado, Catalonia (Spain), Gerona 1870

Daily Report. West Europe 1991.

Decreto de Nueva Planta, 1716, http://pares.mcu.es/ParesBusquedas20/catalogo/description/ 3281950.

Domínguez Ortiz A., The Revolt of Catalonia against Philip IV, „Past \& Present” 1964, nr 39.

Dowling A., The Rise of Catalan Independence. Spain's Territorial Crisis, Routledge 2017.

Ealham Ch., Class, Culture and Conflict in Barcelona, 1898-1937, Routledge 2004.

El Consulado del Mar, http://www.casallotja.com/introducci.

Elliott J.H., The Revolt of Catalans, Cambridge 1963.

Elliott J.H., Scots and Catalans. Union and Disunion, New Haven 2018.

Falkner J., The War of the Spanish Succession 1701-1714, South Yorkshire 2015.

Figueres J.M., Valenti Almirall, Forjador del Catalanisme Politic, Barcelona 1990.

Fishman R.M., Working-Class Organization and the Return to Democracy in Spain, Ithaca 2019.

Florensa i Soler N., Güell M., PRO DEO, PRO REGI, ET PRO PATRIA. La revolució catalana i la campanya militar de 1640 a les terres de Tarragona, Barcelona 2005.

Fons i Duocastella C., La Caputxinada. Frares compromesos amb el país i la llibertat, Barcelona 2016.

Fradera J.M., Cultural Nacional en una Societat Dividida, Barcelona 1992.

Freedman P., Cowardice, Heroism and the Legendary Origins of Catalonia, „Past \& Present” 1988, nr 121.

Gamson W., Strategy of Social Protest, Belmont 1975.

Greer S.L., Nationalism and Self-Government. The Politics of Autonomy in Scotland and Catalonia, Albany 2012.

Güell Ampuero C., The Failure of Catalanist Opposition to Franco (1939-1950), London 2006. 
Guibernau M., Catalan Nationalism. Francoism, Transition and Democracy, Routledge 2004.

Guise R., Two Wheels Over Catalonia. Cycling the Back Roads of North-Eastern Spain, Chichester 2011.

Hroch M., Małe narody Europy. Perspektywa historyczna, Wrocław 2003.

Hughes R., The Spectacle of Skill. Selected Writings of Robert Hughes, New York 2015.

Kark Ch., From parlor to politics. Catalan romantic rationalism as a bourgeois political instrument, „LL Journal” 2, 2015, nr 2.

Linz J., Early State-Building and Late Peripheral Nationalisms Against the State. The Case of Spain, [w:] Building States and Nations. Analyses by Region, red. S.N. Eisenstadt, S. Rokkan, Beverly Hills 1973.

Llobera J.R., The idea of Volksgeist in the formation of Catalan nationalist ideology, „Ethnic and Racial Studies" 1983, nr 6.

Llobera J.R., Foundations of National Identity. From Catalonia to Europe, New York 2004.

Lluch J., Visions of Sovereignty. Nationalism and Accommodation in Multinational Democracies, Philadelphia 2014.

McRoberts K., Catalonia. Nation Building Without a State, New York-Oxford 2001.

Minder R., The Struggle for Catalonia Rebel Politics in Spain, London 2017.

Miravitlles J., Critica del 6 d'octubre, [w:] E. Ucelay de Cal, Estat Catalá. The Strategies of separation and revolution, of Catalan Radical Nationalism (1919-1933), New York 1979.

Nación y nacionalismos en la España de las autonomías, red. I. Sepúlveda Muñoz, Madrid 2018.

Nonaka I., Takeuchi H., Kreowanie wiedzy w organizacji. Jak spótki japońskie dynamizuja procesy innowacyjne, przeł. E. Nalewajko, Warszawa 2000.

Offe C., New Social Movements. Challenging the Boundaries of Institutional Politics, „Social Research" 1985, nr 52 (4).

Pagès i Blanch P., La transició democràtica als Països Catalans. Història i memòria, València 2011.

Pohlig M., Schaich M., The War of the Spanish Succession: New Perspectives, Oxford 2018.

Preston P., Coming of the Spanish Civil War, Routledge 2003.

de Puig i Oliver J., Rodó Rodà J., Comas Closas F., 125 anys de les Bases de Manresa (1892-2017).

Memòria del programa i miscelllània sobre la Manresa de fa 125 anys, Barcelona 2019.

Roca i Albert J., Miejsce Barcelony w cywilizacji europejskiej, przeł. S. Kuźmicz, [w:] Barcelona i Kraków. Zmieniające się wizje - wizje zmian. Materiaty międzynarodowej konferencji zorganizowanej w dniach 29-30 marca 2007, red. J. Purchla, Kraków 2008.

Santamaria Balaguer F.X., Prat De La Riba I La Institucionalització D'un Model De Cultura Catalana. L'obra Cultural I Pedagògica, Barcelona 2010.

Sroka A., Hiszpańska droga do federalizmu, Wrocław 2008.

Stalder F., M. Castells. Teoria społeczeństwa sieci, przeł. M. Król, Kraków 2012.

Tarrow S., Power in Movement, Cambridge 2009.

Tortella G., Catalonia in Spain. History and Myth, Cham 2017.

Vargas M.A, Constructing Catalan Identity. Memory, Imagination, and the Medieval, Cham 2018.

Venteo D., Barcelona. A Historical Guide to the Contemporary City, Barcelona 2014.

Vilaregut R., Terra Lliure. La temptació armada a Catalunya, Columna 2004.

Studia nad Autorytaryzmem i Totalitaryzmem 43, nr 1, 2021

(C) for this edition by CNS 